Peer reviewed only Published between: Published from year:

\title{
Evaluation of Hydrocarbon Emulsification and Heavy Metal Detoxification Potentials of Sophorolipid Biosurfactants Produced from Waste Substrates using Yeast and Mushroom.
}

AuthorsE. F. Ahuekwe (University of Port Harcourt) | B. E. Okoli (University of Port Harcourt) | H. O. Stanley (University of Port Harcourt) | B. Kinigoma (University of Port Harcourt)DOlhttps://doi.org/10.2118/183578-MSDocument IDSPE-183578-MS

PublisherSociety of Petroleum EngineersSourceSPE African Health, Safety, Security, Environment, and Social Responsibility

Conference and Exhibition, 4-6 October , Accra, GhanaPublication Date2016

Abstract

Insolubility challenges have reduced the efficiency and rate of environmental bioremediation of hydrophobic pollutants occurring in hydrocarbons, soil and water environments. As biosurfactants, sophorolipids possess the unique capacity of activity at the interface of immiscible liquids or solid-liquid phases, thus reducing surface and interfacial tensions through emulsification, dispersion, foaming and wetting, with advantages of stability, ecological acceptability and ability to be produced from renewable and cheaper substrates. In light of the above, this study was aimed at assessing the hydrocarbons emulsification and heavy metals detoxification efficiencies of sophorolipid biosurfactants produced from harvested mushrooms and yeasts isolated from a hydrocarbon contaminated site in Obohia, Abia State, Nigeria. Isolates were cultured on an optimized media fortified with agro-industrial waste substrates of rice bran and food industry waste oil as hydrophilic and hydrophobic sources of carbon, respectively. However sophorolipids production from the yeast, Candida bombicola, was confirmed by the emulsification index after $24 \mathrm{~h}$, surface tension (ST), FT-IR spectroscopy and GC-MS analyses. Solubilization of selected hydrocarbons (used engine oil, kerosene, unused engine oil, diesel and crude oil) was observed with percentage emulsification activities at 60.7, 56.7, 46.9, 44.8 and $40.0 \%$, respectively. Furthermore, various concentrations of chromium, lead, zinc, copper and cadmium salt solutions incubated with culture supernatants of sophorolipids for $24 \mathrm{~h}$ were observed to remove $43.41 \%$ chromium from a 10mg/l salt solution and 23.11( Cr), $9.93(\mathrm{~Pb}), 7.29(\mathrm{Zn}), 4.96(\mathrm{Cu})$ and 15.71 (Cd) from the highly toxic $70 \mathrm{mg} / \mathrm{L}$ salt solutions upon analysis via atomic absorption spectrometry. Our results indicate that sophorolipid biosurfactants could enhance the rate of bioremediation efficiency by emulsifying, solubilizing and detoxifying environmental contaminations of hydrocarbons and heavy metals respectively. Sophorolipids of agro-industrial waste origin possess good surface-active properties that can facilitate the solubilization, dispersion and desorption of hydrophobic environmental contaminants for microbial uptake and bioremediation.

File Size $\quad 6 \mathrm{MB} \quad$ Number of Pages $\quad 16$ 
Abouseoud, M., Maachi, R., and Amrane, A. (2007): Biosurfactant Production from Olive Oil by Pseudomonas fluorescens. Communicating Current Research and Educational Topics in Applied Microbiology, A. Mendez-Vilas (Ed.). 340-346.

Accorsini, F. R., Mutton, M. J. R., Lemos, E. G. M. and Benincasa, M. (2012): Biosurfactant Production by Yeasts using Soybean Oil and Glycerol as Low Cost Substrate. Brazilian Journal of Microbiology. 116-125.

Adamu, A., Ijah, J. J. U., Riskuwa, M. L., Ismail, H. Y. and Ibrahim, U. B. (2015): Study on Biosurfactant Production by Two Bacillus Species. International Journal of Scientific Research in Knowledge. 3 (1): 013020.

Adewuyi, A., Ayodele, O. R. and Ololade, A. A. (2013): Antibacterial Activities of Nonionic and Anionic Surfactants from the Seed Oil of Citrullus lanatus. Jundishapur J Microbiol. 6 (3): 205-208.

Ahuekwe, E. F., Okoli, B. E., Stanley, O. H. and Kinigoma, B. (2016): Experimental Investigation of Sophorolipid Biosurfactants Produced by Candida and Pleurotus Species using Waste Oils and Rice Bran and Their Oilfield Benefits. Journal of Advances in Biology and Biotechnology. 7 (4): 1-15.

Amaral, P. F. F., da Silva, J. M., Lehocky, B. M., Barros-Timmons, A. M. V., Coelho, M. A. Z., Marrucho, I. M. and Coutinho (2006): Production and Characterization of a Bioemulsifier from Yarrowia lipolytica. Process Biochemistry. 41, 1894-1898.

Aneja, M. K., Sharma, S., Fleischmann, F., Stich, S., Heller, W., Bahnweg, G., Munch, J. C. and Schloter, M. (2006): Microbial Colonization of Beech and Spruce Litter-influence of Decomposition Site and Plant Litter Species on the Diversity of Microbial Community. Microb Ecol. 52, 127-135.

Banat, I. M., Franzetti, A., Gangolfi, I., Bestetti, G., Martinotti, M. G., Fracchia, L., Smyth, T. J. and Marchant, R. (2010): Microbial Biosurfactants Production, Applications and Future Potential. Appl. Microbiol. Biotechnol. 87, 427-444.

Batista, R. M., Rufino, R. D., Luna, J. M., Souza, J. E. G. and Sarubbo, L. A. (2010): Effect of Medium Components on the Production of a Biosurfactant from Candida tropicalis Applied to the Removal of Hydrophobic Contaminants in Soil. Water Environ. Res., 82, 418-425. 
Bhardwaj, G., Cameotra, S. S. and Chopra, H. K. (2013): Biosurfactants from Fungi: A Review. J. Pet. Environ. Biotechnol. 4, 160-165.

Calvo, C., Silva-Castro, G. A., Uad, I., García Fandiño, C., Laguna, J. and González-López, J. (2008): Efficiency of the EPS Emulsifier Produced by Ochrobactrum anthropi in Different Hydrocarbon Bioremediation Assays. J. Ind. Microbiol. Biotechnol. 35, 1493-1501.

Cavalero, D. A., and Cooper, D. G. (2003): The Effect of Medium Composition on the Structure and Physical State of Sophorolipids Produced by Candida bombicola ATCC 22214. J Biotechnol 103, 31-41.

Chakrabarti, S. (2012): Bacterial Biosurfactant: Characterization, Antimicrobial and Metal Remediation Properties. Ph.D. Thesis, National Institute of Technology, Surat, India.

Chandran, P. and Das, N. (2011): Characterization of Sophorolipid Biosurfactant produced by Yeast Species Grown on Diesel Oil. International Journal of Science and Nature 2 (1): 63-71.

Coimbra, C. D., Rufino, R. D., Luna, J. M. and Sarubbo, L. A. (2009): Studies of the Cell Surface Properties of Candida Species and Relation with the Production of Biosurfactants for Environmental Applications. Current Microbiology. 58, 245-249.

Cooper, D. G., and Goldenberg, B. G. (1987): Surface-active Agents from Two Bacillus Species. Appl. Environ. Microbiol. 53, 224-229.

Daverey, A. and Pakshirajan, K. (2010): Sophorolipids from Candida bombicola using Mixed Hydrophilic Substrates: Production, Purification and Characterization. Colloids Surface Biointerfaces 79, 246-256.

de Oliveira, M. R., Magri, A., Baldo, C., Camilios-Neto, D., Minucelli, T. and Celligoi, M. A. P. C. (2015): Review: Sophorolipids A Promising Biosurfactant and its Application. International Journal of Advanced Biotechnology and Research. 6 (2): 161-174.

Donio, M. B. S., Ronica, F. A., Viji, V. T., Velmurugan, S., Jenifer, J. S. C. A., Michaelbabu, M., Dhar, P. and Citarasu, T. (2013): Halomonas sp. BS4, A Biosurfactant Producing Halophilic Bacterium Isolated from Solar Salt Works in India and their Biomedical Importance. Springer Plus 2, 149-159. 
Elshafie, A., Al-Bahry, S. N., Al-Wahaibi, Y. M., Al-Bemani, A. S., Joshi, S. J. and Al-Maqbali, D. (2013): Sophorolipids Production by Candida bombicola ATCC 22214 and its Possible Application in Enhancing Oil Recovery, In 4 The International Symposium on Applied Molecular Microbiology in Oil Systems (ISMOS). 1-63.

Haba, E., Espuny, M. J., Busquets, M. and Manresa, A. (2000): Screening and Production of Rhamnolipids by Pseudomonas aeruginosa 47T2 NCIB 40044 from Waste Frying Oils. Journal of Applied Microbiology. 88, 379-387.

Hazra, C., Kundu, D., Ghosh P., Joshi, S., Dandi N, Chaudhari, A. (2011). Screening and Identification of Pseudomonas aeruginosa ABS for Improved Production, Characterization and Application of a Glycolipid Biosurfactant using Low-cost Agro-based Raw Materials. J. Chem. Technol. Biotechnol. 86, 185-198.

Helmy, Q., Kardena, E., Nurachman, Z. and Wisjnuprapto. (2010): Application of Biosurfactant Produced by Azotobacter vinelandii AV01 for Enhanced Oil Recovery and Biodegradation of Oil Sludge.

International Journal of Civil and Environmental Engineering. 10 (1): 7-14.

Ismail, H. Y., Ijah, U. J. J., Riskuwa, M. L. and Ibrahim, A. A. (2014): Biodegradation of Spent Engine Oil by Bacteria Isolated from the Rhizosphere of Legumes Grown in Contaminated Soil. International Journal of Environment. 3 (2), 85-97.

Jain D. K., Collins-Thompson D. L., Lee H. and Trevors, T. A. (1991): Drop Collapsing Test for Screening Surfactant-producing Microorganisms. Journal of Microbiological Methods. 13, 271-279.

Kasture, M. B., Patel, P., Prahbune, A. A., Ramana, C. V., Kulkarni, A. A. and Prasad, B. L. V. (2008): Synthesis of Silver Nanoparticles by Sophorolipids: Effects of Temperature and Sophorolipid Structure on the Size of Particles. Journal of Chemical Sciences. 120 (6): 515-520.

Kim, K., Yoo, D., Kim, Y., Lee, B., Shin, D. and Kim, E. K. (2002): Characteristics of Sophorolipid as an Antimicrobial Agent. Journal of Microbiology and Biotechnology 12, 235-241.

Kitamoto, D., Ikegami, T., Suzuki, G. T., Sasaki, A., Takeyama, Y., Idemoto, Y., Koura, N. and Yanagishita, H. (2001): Microbial Conversion of n-alkanes into Glycolipid Biosurfactants, Mannosylerythritol Lipids by Pseudozyma (Candida antartica). Biotechnol. Lett. 23, 1709-1714. 
Klein, J. and Wagner, F. (1987): Different Strategies to Optimize the Production Phase of Immobilized Cells. Annals of the New York Academy of Sciences. 501, 306-316.

Luna, J. M., Rufino, R. D., Campos-Takaki, G. M. and Sarubbo, L. A. (2012): Properties of the Biosurfactant Produced by Candida sphaerica Cultivated in Low-cost Substrates. Chemical Engineering Transactions. 27, 67-72.

Mabrouk, M. E. M., Youssif, E. M. and Sabry, S. A. (2014): Biosurfactant Production by a Newly Isolated Soft Coral-associated Marine Bacillus sp. E34: Statistical Optimization and Characterization. Life Sci. J. 11 (10): 756-768.

Makkar, R. S., Cameotra, S. S. and Banat, I. M. (2011): Advances in Utilization of Renewable Substrates for Biosurfactant Production. AMB Exp. 1 (1): 5.

Maslin, P. and Maier, R. M. (2000): Rhamnolipid Enhanced Mineralization of Phenanthrene by Indigenous Microbial Populations in Organic-metal Contaminated Soils. Bioremed J. 4, 295-308.

Munguia, T. and Smith, C. A. (2001): Surface Tension Determination through Capillary Rise and Laser Diffraction Patterns. J Chem Educ. 78(3): 343-344.

Nalini, S. and Parthasarathi, R. (2013): Biosurfactant Production by Serratia rubidaea SNAU02 Isolated from Hydrocarbon Contaminated Soil and its Physico-chemical Characterization. Bioresource Technology. 147, 619-622.

Nguyen, T. T., and Sabatini, D. A. (2011): Characterization and Emulsion Properties of Rhamnolipid and Sophorolipid Biosurfactants and their Applications. International Journal of Molecular sciences 12, 1232-1244.

Nitschke, M. and Costa, S. G. (2007): Biosurfactants in Food Industry. Trends Food Sci. Technol. 18, 252259.

Okore, C., Mbanefo, O., Onyekwere, B., Onyewenjo, S. and Abba-Father, C. (2013): Isolation and Characterization of Biosurfactants Producing Bacteria from Oil Polluted Soil. Journal of Natural Sciences Research. 3 (5), 119-122. 
Pacwa-Plociniczak, M., Plaza, G.A., Piotrowska-Seget, Z. and Cameotra, S. S. (2011): Environmental Applications of Biosurfactants: Recent Advances. Int. J. Mol. Sci. 12, 633-654.

Pérez, R. M., Abalos, A., Gómez, J. M. and Cantero, D. (2007): Biosorption of Heavy Metals by Pseudomonas aeruginosa Isolated from a Petroleum Contaminated Site. Adv. Mater. Res. 20-21, 615618.

Pradhan, K., Pradhan, N., Sukla, L. B., Panda, P. K. and Mishr, B. K. (2014): Inhibition of Pathogenic Bacterial Biofilm by Biosurfactant Produced by Lysinibacillus fusiformis S9. Bioprocess Biosyst. Eng. 37, 139-149.

Rodriguez, L. R., Teixeira, J. A. and Oliveira, R. (2006): Low-cost Fermentative Medium for Biosurfactant Production by Probiotic Bacteria. Biochemical Eng J. 32, 135-142.

Rosa, C. F. C., Freire, D. M. G. and Ferraz, E. C. (2015): Biosurfactant Microfoam: Application in the Removal of Pollutants from Soil. J. Environ. Chem. Eng. 3, 89-94.

Rosenberg, E. and Ron, E. Z. (1999): High- and Low-molecular Mass Microbial Surfactant. Appl. Microbiol. Biotechnol. 52, 154-262.

Rufino, R. D., Sarubbo, L. A. and Campos-Takaki, G. M. (2007): Enhancement of Stability of Biosurfactant Produced by Candida lipolytica using Industrial Residue as Substrate. World J. Microbiol. Biotechnol. 23, 729-734.

Saharan, B. S., Sahu, R. K. and Sharma, D. (2011): A Review on Biosurfactants: Fermentation, Current Developments and Perspectives. Genetic Engineering and Biotechnology Journal. 1-29.

Salihu, A., Abdulkadir, I. and Almustapha, M. N. (2009): An Investigation for Potential Development on Biosurfactants. Biotechnology and Molecular Biology Reviews. 3 (5), 111-117.

Sandrin, T. R., Chech, A. M. and Maier, R. M. (2000): A Rhamnolipid Biosurfactant Reduces Cadmium Toxicity during Naphthalene Biodegradation. Appl. Environ. Microbiol. 66, 4585-4588. 
Sarubbo A. L., Santos, D. K. F., Rufino, R. D., Luna J. M. and Santos V. A. (2016): Biosurfactants:

Multifunctional Biomolecules of the 21st Century. International Journal of Molecular Sciences. 17, 401431.

Satpute, S. K., Bhawsar, B. D., Dhakephalkar, P. K. and Chopade, B. A. (2008): Assessment of Different Screening Methods for Selecting Biosurfactant Producing Marine Bacteria. Ind. J. Mar. Sci. 37, 243-250.

Shah, S. and Prabhune, A. (2007): Purification by Silica Gel Chromatography using Dialysis Tubing and Characterization of Sophorolipids Produced from Candida bombicola Grown on Glucose and Arachidonic Acid. Biotechnology Letters. 29 (2), 267-272.

Shoeb, E., Akhlaq, F., Badar, U., Akhter, J. and Imtiaz, S. (2013): Classification and Industrial Applications of Biosurfactants. Academic Research International. 4(3): 243-248.

Siegmund, I. and Wagner, F. (1991): New Method for Detecting Rhamnolipids Excreted by Pseudomonas Species during Growth on Mineral Agar. Biotechnol. Tech. 5, 265-268.

Sinha, S. N., and Paul, D. (2012): Detoxification of Heavy Metals by Biosurfactants. Bulletin of Environmental and Scientific Research. 1 (3-4) 1-3.

Sobrinho, H.B.S., Rufino, R. D., Luna, J. M., Salgueiro, A. A., Campos-Takaki, G. M., Leite, L. F. C. and Sarubbo, L. A. (2008): Utilization of Two Agro-industrial By-products for the Production of a Surfactant by Candida sphaerica UCP 0995. Process Biochem. 43, 912-917.

Suwansukho, P., Rukachisirikul, V., Kawai, F. and H-Kittikun, A. (2008): Production and Applications of Biosurfactant from Bacillus subtilis MUV4. Songklanakarin J. Sci. Technol. 30, 87-93.

Velioglu, Z. and Öztürk-Ürek, R. (2015): Biosurfactant Production by Pleurotus ostreatus in Submerged and Solid-state Fermentation Systems. Turkish Journal of Biology. 39, 160-166.

Vijayakumar, S. and Saravanan, V. (2015): Biosurfactants-types, Sources and Applications. Res. J. Microbiol. 10, 181-192. 
Youssef, N. H., Duncan, K. E., Nagle, D. P., Savage, K. N., Knapp, R. M. and Mclnerney, M. J. (2004): Comparison of Methods to Detect Biosurfactant Production by Diverse Microorganisms. J Microbiol Meth. 56, 339-347.

Other Resources

Looking for more?

Some of the OnePetro partner societies have developed subject- specific wikis that may help.

PetroWiki was initially created from the seven volume Petroleum Engineering Handbook (PEH) published by the Society of Petroleum Engineers (SPE).

The SEG Wiki is a useful collection of information for working geophysicists, educators, and students in the field of geophysics. The initial content has been derived from : Robert E. Sheriff's Encyclopedic Dictionary of Applied Geophysics, fourth edition. 